\title{
The success of cardiotocography in predicting perinatal outcome
}

\section{Kardiyotokografinin perinatal sonuçları öngörmedeki başarısı}

\author{
Alpaslan Kaban ${ }^{1}$, Hüseyin Cengiz ${ }^{2}$, Işık Kaban², Alim Özcan ${ }^{1}$, Sema Karakaş² \\ ${ }^{1}$ Arnavutköy State Hospital, Department of Gynecology and Obstetrics, Istanbul, Turkey \\ ${ }^{2}$ Bakirköy Dr. Sadi Konuk Teaching and Research Hospital, Department of Gynecology and Obstetrics, Istanbul, Turkey
}

\begin{abstract}
Objectives: The determination of the fetal condition during labor is important to minimize fetal death due to asphyxia and the neurological sequelae of fetal hypoxia. This study evaluated the success of fetal cardiotocography in predicting perinatal consequences.

Materials and methods: This study enrolled 101 full-term pregnant women admitted for delivery to Vakif Gureba Training and Research Hospital between October 2009 and February 2010. Women were included if they were aged 18-45 years and within 36-41 weeks of gestation. During a 20 -min period of fetal monitoring, a change in FHR (fetal heart rate) lasting for $15 \mathrm{~s}$ or two elevated runs of 15 beats was evaluated as a reactive NST (non-stress test). The umbilical artery $\mathrm{pH}$ was used as the "gold standard" for assessing fetal asphyxia.
\end{abstract}

Results: The mean age of the women included in the study was $27.82 \pm 5.29$ years, the average parity was 1.09 \pm 0.96 . The $\mathrm{pH}$ was normal in 85 neonates, while 13 had fetal asphyxia. No significant difference in umbilical cord blood $\mathrm{pH}, \mathrm{pO}_{2}$, or $\mathrm{pCO}_{2}$ was observed between these two groups $(p=0.497, p=0.722$, and $p=0.053$, respectively. No significant difference in maternal age, parity, or birth weight was found between the group with fetal distress based on CTG (cardiotocography) and the normal group.

Conclusion: Cardiotocography is an important test during labor for labor management, it is insufficient for predicting the perinatal outcome. Therefore, labor should be evaluated on an individualized basis. J Clin Exp Invest 2012; 3(2): 168-171

Key words: Apgar score, blood gas analysis, caesarean section, cardiotocography

\section{INTRODUCTION}

Currently, the evaluation of fetal health is among the main concerns of obstetricians. It requires the recognition and treatment of disease in utero. Whereas the prevention and treatment of diseases

\section{ÖZET}

Amaç: Doğum sırasında fetal koşulları belirlemek; asfiksi ve fetal hipoksideki nörolojik sekellere bağlı fetal ölümleri minimuma indirmek için önemlidir. Bu çalışmanın amacı, perinatal sonuçları öngörüde, fetal kardiyotokografinin başarısını değerlendirmektedir.

Gereç ve yöntem: Bu çalışmaya Ekim 2009 ve Şubat 2009 tarihleri arasında Vakıf Gureba Eğitim ve Araştırma Hastanesinde doğum yapmayı kabul etmiş, 101 term gebe kadın alındı. 36-41 gebelik haftasında ve 18-45 yaşları arasındaki gebeler çalışmaya dahil edildi. 20 dakikalık fetal izlem periyodunda fetal kalp atımlarında en az iki adet; 15 saniye süren ve 15 atımlık artışları olan olgular, reaktif NST (Non-stress test) olarak kabul edildi. Umblikal arter pH fetal asfiksiyi değerlendirmede 'altın standart' olarak kullanıldı.

Bulgular: Çalışmaya katılan kadınların ortalama yaşı $27.82 \pm 5.29$ ve ortalama pariteleri $1.09 \pm 0.96$ idi. 85 yeni doğanda $\mathrm{pH}$ normalken, 13 tanesinde fetal asfiksi görüldü. Bu iki grup arasında göbek kordon kanı (kök hücre kaynağı) $\mathrm{pH}, \mathrm{pO}_{2}$, ya da $\mathrm{pCO}_{2}$ da anlamlı değişiklikler gözlenmedi (sırasıyla $p=0.497, p=0.722$, and $p=0.05$ ). Kardiyotokografiye dayalı fetal distres ve normal grup arasında annelik yaşı, parite ya da doğum ağırlığında anlamlı derecede farklılık gözlemlenmedi.

Sonuç: Kardiyotografi doğum yönetimi için doğum sırasında önemli bir testtir, ancak perinatal sonuçları öngörmek için yetersizdir. Bu yüzden doğum kişiselleştirmeye dayalı bir şekilde değerlendirilmelidir.

Anahtar kelimeler: Apgar skoru, kan gazlari analizi, sezaryen doğum, kardiyotografi

in the mother were once the focus of obstetrics, the same importance is now given to the fetus. The fetus' health is evaluated, in part, by assessment of the fetal heart rate (FHR). This assessment involves identification of two general types of FHR patterns: those that may be associated with adverse fetal or 
neonatal outcomes (ie, nonreassuring patterns) and those that are indicative of fetal well-being. But there is no evidence from randomized trials that proves antepartum FHR monitoring results in a decreased risk of fetal death. ${ }^{1}$

The determination of the fetal condition during labor is important to minimize fetal death due to asphyxia and the neurological sequelae of fetal hypoxia. Clinical indicators of fetal distress often give false-positive results, as they occur more frequently than fetal death or the sequelae of hypoxia. ${ }^{2,3} \mathrm{De}-$ spite its shortcomings, most clinics use cardiotocography (CTG) to determine intrapartum fetal distress and the need for obstetric intervention during labor. However, the false-positive rate for a reactive CTG is $2-5 \%$, versus $50-80 \%$ for non-reactive CTG. ${ }^{4,5}$ Studies indicate that the 1-week perinatal mortality rate for reactive CTG is 3-5/1000. ${ }^{4}$ Consequently, a good perinatal outcome is expected when CTG results are normal, but not when they are abnormal.

With the accumulation of over 35 years of experience, the interpretation of fetal heart rate (FHR) patterns has improved and characteristic FHR features in normal and abnormal fetuses can be identified. Nevertheless, the identification of truly threatened fetuses based on FHR abnormalities is difficult, and most fetal distress does not clearly reflect the endangerment of the fetus.

Within the context of ongoing debate about the interpretation of CTG patterns, this study evaluated the success of fetal CTG in predicting perinatal consequences.

\section{MATERIALS AND METHODS}

This study enrolled 101 full-term pregnant women admitted for delivery to "XXX Hospital" between October 2009 and February 2010. Women were included if they were aged 18-45 years and within 3641 weeks of gestation. Women whose ages or gestation status fell outside these ranges, those with a systemic disease, and those who were regular drug users were excluded.

On admission, the patients underwent routine obstetric examinations, including an ultrasonographic evaluation of the cervical length.

For non-stress testing (NST), Hewlett-Packard 50A [Palo Alto, CA, US] electronic fetal monitor was used. During a 20-min period of fetal monitoring, a change in FHR lasting for $15 \mathrm{~s}$ or two elevated runs of 15 beats was evaluated as a reactive NST. Non-reactive NST patients were monitored for 40 min. Patients with at least two contractions within
10 min on CTG and who were considered to be in labor based on cervical effacement and dilatation were admitted to the labor room. This study included women who had undergone a previous cesarean section.

Tachycardia, late deceleration, variability reduction, complicated variable decelerations, and prolonged bradycardia on CTG were interpreted as pathological. All patients gave birth within 12 h. Immediately after birth, before the neonate's first breath, the umbilical cord was clamped at two points with Kocher clamps and cut. The umbilical artery was immediately identified in the cord attached to the placenta and 2-3 $\mathrm{mL}$ of blood was aspirated with a 3-mL syringe (Becton-Dickinson, Rutherford, NJ). To prevent air contact, the syringe tip was sealed with a special cover. The blood was delivered to the laboratory within 5-10 min. The umbilical artery $\mathrm{pH}$ was used as the "gold standard" for assessing fetal asphyxia: an umbilical artery $\mathrm{pH}<$ 7.20 was assessed as asphyxia and a $\mathrm{pH}<7.10$ as severe asphyxia. Neonates with Apgar scores $<7$ were assessed as depressed, those with scores of 4-6 as slightly depressed, and those with scores $<4$ as severely depressed.

\section{Statistical Analysis}

The data were analyzed using SPSS 15.0 (SPSS 15.0 for Windows, SPSS Inc., Chicago, IL, USA). Groups were compared using the t-test or MannWhitney U-test as appropriate. A P-value $<0.05$ was considered statistically significant.

\section{RESULTS}

The study enrolled 101 women who gave birth in our clinic between October 2009 and February 2010. Of these, blood gases could not be determined in three cases because of technical problems. Of the remaining patients, the $\mathrm{pH}$ was normal in 85 neonates, while 13 had fetal asphyxia. Of the 101 women, $59(58.4 \%)$ had spontaneous vaginal deliveries, while $42(41.6 \%)$ underwent caesarean section, including 28 pregnant women who had previous cesarean births: six because of fetal distress, four with cephalopelvic disproportion, three with breech presentations, and one with a previous myomectomy. The mean age of the women included in the study was $27.82 \pm 5.29$ years, the average parity was 1.09 \pm 0.96 , and the mean birth weight was $3340.40 \pm$ $453 \mathrm{~g}$ (Table 1). Of the 13 asphyxtic neotanes, 5 of them had a non-reactive NST and 8 of them had reactive NST. Eighty five neonates whose $\mathrm{pH}$ was normal, had all reactive NST. 
No significant difference in maternal age, parity, or birth weight was found between the group with fetal distress based on CTG and the normal group. No significant difference in umbilical cord blood $\mathrm{pH}$, $\mathrm{pO}_{2}$, or $\mathrm{pCO}_{2}$ was observed between these two groups $(p=0.497, p=0.722$, and $p=0.053$, respectively; Table 2).

The 1- and 5-min Apgar scores were compared in the normal and fetal-distress groups identified by CTG. No significant difference was found according to either score.

Table 1. Average values for the patients studied

\begin{tabular}{lccccc}
\hline & $\mathrm{n}$ & Min & Max & Mean & $\begin{array}{c}\text { Standard } \\
\text { deviation }\end{array}$ \\
\hline $\begin{array}{l}\text { Maternal age } \\
\text { (years) }\end{array}$ & 101 & 18 & 40 & 27.82 & 5.29 \\
Birth weight (g) & 101 & 2,220 & 4,900 & $3,340.40$ & 453.30 \\
Apgar (1 min) & 101 & 6 & 9 & 7.97 & 0.66 \\
Apgar (5 min) & 101 & 7 & 10 & 9.08 & 0.50 \\
Parity & 101 & 0 & 4 & 1.09 & 0.96 \\
pH & 98 & 6.97 & 7.43 & 7.28 & 0.08 \\
$\mathrm{PCO}_{2}$ & 98 & 30 & 99 & 52.54 & 9.52 \\
$\mathrm{PO}_{2}$ & 98 & 4 & 40 & 21.55 & 6.29 \\
\hline
\end{tabular}

$\mathrm{pH}$ (Power of Hydrogen); $\mathrm{pO}_{2}$ (Partial Pressure of Oxygen); $\mathrm{PCO}_{2}$ (Partial Pressure of carbon dioxide); SD, standard deviation.

Table 2. Comparison of the results of blood gas analysis according to the cardiotocography results

\begin{tabular}{|c|c|c|c|c|c|c|c|}
\hline & NST & $n$ & Mean & SD & Min & $\operatorname{Max}$ & $P$ \\
\hline $\mathrm{pH}$ & $\mathrm{R}$ & 93 & 7.28 & 0.08 & 6.97 & 7.43 & 0.497 \\
\hline $\mathrm{pH}$ & NR & 5 & 7.31 & 0.07 & 7.20 & 7.40 & \\
\hline $\mathrm{PCO}_{2}$ & $\mathrm{R}$ & 93 & 52.61 & 9.58 & 30 & 99 & 0.722 \\
\hline $\mathrm{PCO}_{2}$ & NR & 5 & 51.20 & 9.01 & 42 & 64 & \\
\hline $\mathrm{PO}_{2}$ & $\mathrm{R}$ & 93 & 21.30 & 6.23 & 4 & 40 & 0.053 \\
\hline $\mathrm{PO}_{2}$ & NR & 5 & 26.20 & 6.02 & 16 & 32 & \\
\hline
\end{tabular}

$\mathrm{pH}$ (Power of Hydrogen); $\mathrm{pO}_{2}$ (Partial Pressure of Oxygen); $\mathrm{pCO}_{2}$ (Partial Pressure of carbon dioxide); NST, non-stress testing; R, reactive NST; NR, non-reactive NST; SD, standard deviation.

\section{DISCUSSION}

There is no proved impact of cardiac fetal monitoring (continuous or intermittent) on perinatal mortality. ${ }^{6}$ Traditionally, obstetricians tended to classify pregnant women as "low" and "high" risk. Although many well-organized methods are available for managing the high-risk group, we need more efficient methods for identifying pregnant women in distress in the low-risk group. ${ }^{4}$ Many clinics still use CTG for intrapartum assessment and the management of labor, despite its shortcomings. In our clinic, we combine CTG with the amniotic fluid index (AFI). The reported 1-week perinatal mortality rate following a reactive CTG is 3-5/1000. ${ }^{4} \mathrm{~A}$ good perinatal outcome can be expected with a normal CTG, but not with an abnormal CTG. Many fetuses show FHR abnormalities during labor, and the identification of truly endangered fetuses is difficult because most abnormal findings do not truly reflect endangerment.

The interpretation of CTG patterns is controversial. For example, Keith et al. ${ }^{7}$ asked 17 experts for their opinions of 50 traces examined at least twice at different times. Approximately $20 \%$ changed their interpretations and $25 \%$ did not agree with the interpretation. ${ }^{7}$ Many studies examining the comprehensive impact of CTG have stated that CTG does not improve the perinatal outcome..$^{8-11}$ According to these studies, CTG determines the perinatal mortality with a sensitivity of $60 \%$ and a specificity $<50 \%$. Visser et al. ${ }^{12}$ identified normal and abnormal patterns of reactive CTG determining fetal distress after birth by examining the umbilical artery gas parameters, and found a sensitivity, specificity, and positive and negative predictive values of $79 \%, 85 \%, 68 \%$, and $91 \%$, respectively. In that study, the positive and negative predictive values were $81 \%$ and $89 \%$, respectively, for decelerations and $88 \%$ and $76 \%$, respectively for variability loss. ${ }^{13}$ Smith et al. (14) analyzed the umbilical cord arterial blood gas in 21 patients undergoing a cesarean section because of abnormal CTG. They found minor degrees of respiratory acidemia and concluded that abnormal CTG traces may be associated with hypoxia, but were unrelated to asphyxia. ${ }^{13} \mathrm{We}$ compared two groups of patients based on CTG and found no significant difference between the fetal-distress and normal groups in terms of umbilical cord blood gas findings and Apgar scores. The most important limitation of our study was the small number of patients. More extensive studies are needed to determine the success of CTG for predicting perinatal outcome.

In conclusion, although CTG is an important test during labor for birth management, it is insufficient for predicting the perinatal outcome. Therefore, labor should be evaluated on an individualized basis.

\section{Conflict of interest: NONE}




\section{REFERENCES}

1. Rouse DJ, Owen J, Goldenberg RL, Cliver SP. Determinants of the optimal time in gestation to initiate antenatal fetal testing: a decision-analytic approach. Am J Obstet Gynecol. 1995;173(5):1357-9.

2. Boylan P. Intrapartum fetal monitoring. Baillieres Clin Obstet Gynaecol 1987;1(1):73-95.

3. Steer PJ, Eigbe I, Lissauer TS, Beard RW. Interrelationships among abnormal cardiotocogram in labor, meconium staining of the amniotic fluid, arterial cord blood $\mathrm{pH}$ and Apgar scores. Obstet Gynecol 1989;74(5):715-21.

4. Yucel A, Yilmazer M, Acar M. Comparison of doppler indices and non-stress test values according to fetal sex in normal term pregnancies. The Medical Journal of Kocatepe 2005; 6(1):19-24.

5. Thacker SB, Berkelman RL. Assessing the diagnostic accuracy and efficacy of selected antepartum fetal surveillance techniques. Obstet Gynecol Surv 1986;41(3):121-41.

6. Bretelle F, Le Du R, Foulhy C. Modality of fetal heart monitoring during labor (continuous or intermittent), telemetry and central fetal monitoring. J Gynecol Obstet Biol Reprod (Paris).. 2008; 37(1 Suppl): 23S-33S.
7. Keith RDF, Beckley S, Garibaldi JM et al. A multicentre comparative study of 17 experts and an intelligent computer system for managing labour using the cardiotocogram. Br J Obstet Gynaecol 1995;102(9):688700.

8. Schneider EP, Hutson JM, Petrie RH. An assessment of the first decade's experience with antepartum fetal heart rate testing. Am J Perinatol 1988;5(2):34-41.

9. Phelan JP: The nonstress test: a review of 3,000 tests. Am J Obstet Gynecol 1981; 139(1):7-10.

10. Kidd LC, Patel NR, Smith R. Non stress antenatal cardiotocography: a prospective randomized controlled trial Br J Obstet Gynaecol 1985;92(11):1156-9.

11. Brown Y. Sawers RS, Parson RJ, Duncan SLB, Cooke ID. The value of antenatal cardiotocography management of high risk pregnancy: a randomized controlled trial. Br J Obstet Gynaecol 1982;89(9):716-22.

12. Visser GHA, Sadovsky G, Nicolaides KH. Antepartum heart rate patterns in small for gestational age third trimester fetuses: correlations with blood gas values obtained at cordocentesis. Am J Obstet Gynecol 1990;162(3):698-703.

13. Smith JH, Anand KJ, Cotes PM, et al. Antenatal fetal heart rate variation in relation to the respiratory and metabolic status of the compromised human fetus. $\mathrm{Br}$ J Obstet Gynaecol 1988;95(10):980-9. 